\title{
KEBUTUHAN KETERAMPILAN KERJA STAF BIDANG LAYANAN REHABILITASI SOSIAL, PEMULANGAN, DAN REINTEGRASI SOSIAL P2TP2A
}

\author{
Andita Ratih ${ }^{1}$, Soni A. Nulhaqim² \\ ${ }^{1}$ Program Studi Ilmu Kesejahteraan Sosial, FISIP Universitas Padjadjaran \\ 2 Pusat Studi CSR, Kewirausahaan Sosial \& Pemberdayaan Masyarakat, FISIP Universitas Padjadjaran \\ (e-mail: andita19001@mail.unpad.ac.id, soni.nulhaqim@unpad.ac.id)
}

\begin{abstract}
ABSTRAK
Pada struktur organisasi PPT terdapat Bidang Layanan Rehabilitasi Sosial, Pemulangan, dan Reintegrasi Sosial yang memiliki tugas untuk: 1) Melakukan pendampingan selama proses penanganan kasus; 2) Melakukan konseling; 3) Melakukan koordinasi dengan instansi terkait untuk pemulangan korban; 4) Membuat laporan perkembangan proses pendampingan pemulangan dan rehabilitasi sosial; dan 5) Melakukan pemantauan sekurang-kurangnya tiga bulan setelah korban dipulangkan ke keluarganya. Penelitian ini membahas tentang kebutuhan keterampilan kerja staf bidang Layanan Rehabilitasi Sosial, Pemulangan, dan Reintegrasi Sosial P2TP2A yang dapat membantu P2TP2A memiliki sumber daya manusia kompeten dalam menjalankan tugas. Maka itu, penelitian ini bertujuan untuk mengetahui ciriciri keterampilan kerja yang perlu dimiliki staf bidang Layanan Rehabilitasi Sosial, Pemulangan, dan Reintegrasi Sosial P2TP2A sebagai bagian dari rencana pelatihan. Keterampilan kerja yang dimaksud terdiri dari beberapa keterampilan, yaitu: 1) Manajemen diri, 2) Komunikasi, 3) Kesadaran pada karir, 4) Kerjasama, 5) Penyelesaian masalah, 6) Keterampilan mengelola teknologi dan informasi, 7) Keterampilan matematik, 8) Keberanian berusaha, 9) Kepemimpinan, dan 10) Kecerdasan emosional. Penelitian ini menggunakan metode kualitatif jenis kajian literatur. Teknik pengumpulan data yang digunakan adalah studi literatur dan kemudian dianalisa menggunakan metode deskriptif dengan jenis analisis pekerjaan. Rumusan ciri-ciri keterampilan kerja yang perlu dimiliki staf bidang Layanan Rehabilitasi Sosial, Pemulangan, dan Reintegrasi Sosial dalam rencana pelatihan diharapkan mampu memberikan gambaran pencapaian sebagai upaya peningkatan profesionalitas kerja.
\end{abstract}

Kata-kata kunci: keterampilan kerja, pelatihan, staf P2TP2A.

\begin{abstract}
P2TP2A Social Rehabilitation, Repatriation and Social Reintegration Services Fields staff have the task to: 1) Assist during the case handling process; 2) Counseling; 3) Coordinate with related agencies for the return of victims; 4) Make a report on the progress of the social assistance and rehabilitation assistance process; and 5) Carry out monitoring at least three months after the victim is returned to his family. This study discusses the employability skills of staff. This study aims to determine the characteristics of employability skills that need to be possessed by staff as part of training plan. The employability skills are: 1) self-management, 2) communication, 3) career awareness, 4) collaboration, 5) problem solving, 6) technology and information management skills, 7) mathematical skills, 8) courage to try, 9) leadership, and 10) emotional intelligence. This research uses a qualitative method of type of literature study. The data collection technique uses a study of literature and then analyzed using descriptive methods with the type of job analysis. The formulation of the characteristics of work skills that need to be possessed by staff in the training plan is expected to be able to provide a picture of achievement as an effort to increase work professionalism.
\end{abstract}

Key words: employability skills, training, P2TP2A staff. 


\section{Pendahuluan}

Pusat Pelayanan Terpadu Pemberdayaan Perempuan dan Anak (P2TP2A) merupakan pusat pelayanan terpadu (PPT) atau lembaga yang dinaungi oleh Kementerian Pemberdayaan Perempuan dan Perlindungan Anak (KPP-PA) dan diamanatkan kepada pemerintah daerah untuk memberikan penanganan kepada korban kekerasan secara komprehensif. Dalam Peraturan Menteri Pemberdayaan Perempuan dan Perlindungan Anak Nomor 5 Tahun 2010 juga dijelaskan bahwa pembentukan PPT dimaksudkan untuk memberikan perlindungan, penanganan dan pemenuhan hak korban yang ada di wilayah Indonesia dan luar negeri dengan memberikan layanan rehabilitasi kesehatan, rehabilitasi sosial, pemulangan dan reintegrasi sosial, bantuan hukum yang diselenggarakan oleh pemerintah dan pemerintah daerah serta perwakilan RI di luar negeri. Amanat tersebut menjadikan P2TP2A sebagai sebuah lembaga yang krusial dalam penyelenggaraan kesejahteraan sosial di Indonesia, khususnya dalam pemberdayaan perempuan dan anak.

Pada struktur organisasi PPT terdapat Bidang Layanan Rehabilitasi Sosial, Pemulangan, dan Reintegrasi Sosial yang memiliki tugas untuk: 1) Melakukan pendampingan selama proses penanganan kasus; 2) Melakukan konseling; 3) Melakukan koordinasi dengan instansi terkait untuk pemulangan korban; 4) Membuat laporan perkembangan proses pendampingan pemulangan dan rehabilitasi sosial; dan 5) Melakukan pemantauan sekurang-kurangnya tiga bulan setelah korban dipulangkan ke keluarganya. Tugas tersebut perlu menjadi perhatian P2TP2A untuk merancang pengembangan sumber daya manusia. Salah satu upaya pengembangan SDM yang dapat dilakukan adalah pelatihan keterampilan kerja.

Employability skills (keterampilan kerja) adalah keterampilan untuk mengidentifikasi masalah dan prioritas yang terkait dengan tindakan individu dan institusi yang terlibat dalam akses terhadap karir (Gazier, 2001). Employability skills disebut juga sebagai keterampilan yang dibutuhkan untuk masuk, bertahan, dan berkembang dalam dunia kerja secara individual maupun kelompok (The Conference
Board of Canada, 2000). Dalam buku Brilliant Employability Skills, Frances (2012) menyatakan keterampilan kerja merupakan cakupan keterampilan yang cukup luas dan dibagi menjadi beberapa keterampilan, yaitu manajemen diri, komunikasi, kesadaran pada karir, kerjasama, penyelesaian masalah, keterampilan mengelola teknologi dan informasi, keterampilan matematik, keberanian berusaha, kepemimpinan, dan kecerdasan emosional.

Hasil penelitian yang dilakukan oleh Suhartini (2015) menjelaskan bahwa keterampilan kerja memiliki pengaruh yang positif dan signifikan terhadap kinerja karyawan, serta membuat karyawan mempertimbangkan realita ketatnya kompetisi dalam bidang ekonomi dan perdagangan, maka sebuah usaha harus memikirkan strategi pengelolaan usaha dengan sumber daya manusia yang berkualitas yang mempunyai pengetahuan, keterampilan dan kemampuan kerja yang baik serta manajerial yang profesional dalam menjalankan usahanya. Penelitian tersebut memberikan gambaran tentang kebutuhan staf bidang Layanan Rehabilitasi Sosial, Pemulangan, dan Reintegrasi Sosial pada employability skills sebagai keterampilan yang perlu dimiliki dalam bekerja.

Pelatihan keterampilan kerja pada staf bidang Layanan Rehabilitasi Sosial, Pemulangan, dan Reintegrasi Sosial dapat membantu P2TP2A memiliki sumber daya manusia yang kompeten dalam menjalankan tugas. Hal tersebut diperkuat oleh pernyataan yang disampaikan Peter Kettner (2002) di dalam buku Achieving Excellence in The Management of Human Service Organizations bahwa pendekatan yang lebih baik dan lebih profesional untuk pelatihan dan pengembangan staf adalah menyiapkan rencana pelatihan lengkap yang akan membantu memastikan bahwa staf berprestasi di tingkat tertinggi. Pelatihan dan pengembangan mengacu pada memperoleh atau mentransfer pengetahuan, keterampilan, dan kemampuan yang dibutuhkan dalam proses melakukan aktivitas atau fungsi tertentu (Niazi, 2011). Kegiatan pelatihan memberikan dampak bagi organisasi dan pekerja secara bersamaan (Abushamsieh, 
2014). Maka itu, penelitian ini bertujuan untuk mengetahui ciri-ciri keterampilan kerja yang perlu dimiliki staf bidang Layanan Rehabilitasi Sosial, Pemulangan, dan Reintegrasi Sosial P2TP2A sebagai bagian dari rencana pelatihan.

\section{Metode}

Penelitian ini menggunakan metode kualitatif jenis kajian literatur. Menurut Creswell (2014), kajian literatur adalah ringkasan tertulis mengenai artikel dari jurnal, buku, dan dokumen lain yang mendeskripsikan teori serta informasi baik masa lalu maupun saat ini, serta mengorganisasikan pustaka ke dalam topik dan dokumen yang dibutuhkan. Teknik pengumpulan data yang digunakan adalah studi literatur terkait analisa terhadap keterampilan kerja dan tugas staf bidang Layanan Rehabilitasi Sosial, Pemulangan, dan Reintegrasi Sosial P2TP2A, di mana peneliti menganalisa secara kritis segmen dari tubuh pengetahuan yang dipublikasikan melalui ringkasan, klasifikasi, dan perbandingan studi penelitian sebelumnya, ulasan literatur, dan artikel teoritis. Hasil penelitian ini kemudian dianalisa menggunakan metode deskriptif dengan jenis analisis pekerjaan. Metode analisis deskriptif dilakukan dengan cara mendeskripsikan dan menganalisa data.

\section{Hasil dan Pembahasan}

\section{A. Keterampilan Kerja}

Keterampilan kerja (employability skills) adalah keterampilan untuk mengidentifikasi masalah dan prioritas yang terkait dengan tindakan individu dan institusi yang terlibat dalam akses terhadap karir (Gazier, 2001). Keterampilan kerja disebutkan juga sebagai keterampilan yang dibutuhkan untuk masuk, bertahan, dan berkembang dalam dunia kerja secara individual maupun kelompok (The Conference Board of Canada, 2000).

Dalam buku berjudul Brilliant Employability Skills, Frances (2012) menyatakan keterampilan kerja merupakan cakupan keterampilan yang cukup luas dan dibagi menjadi beberapa keterampilan sebagai berikut:

1. Keterampilan Manajemen Diri

Keterampilan manajemen diri adalah keterampilan untuk menerima tanggung jawab, fleksibilitas, ketahanan, inisiatif, ketegasan yang tepat, manajemen waktu, dan kesiapan untuk memperbaiki kinerja sendiri berdasarkan umpan balik atau pembelajaran reflektif (Central Bureau of Investigation, 2011).

2. Keterampilan Kerjasama

Keterampilan kerjasama adalah kemampuan individu untuk menghormati orang lain, bekerja dengan orang lain, bernegosiasi atau meyakinkan, berkontribusi dalam diskusi, proyek, atau tugas, dan memiliki kesadaran akan saling ketergantungan dengan orang lain (Central Bureau of Investigation, 2011).

3. Kesadaran pada Karir

Kesadaran pada karir merupakan kemampuan individu untuk mengenali karier sehingga individu mampu memahami target, tujuan, dan tantangan dalam karir (Syafitri \& Heriyanto, 2013).

4. Keterampilan Menyelesaikan Masalah

Keterampilan menyelesaikan masalah merupakan kemampuan individu dalam mengenali, mengidentifikasi, mendefinisikan, menganalisa fakta dan situasi dari masalah yang dihadapi, serta menerapkan pemikiran kreatif untuk mengembangkan solusi yang tepat melalui penafsiran strategi yang memungkinkan (Central Bureau of Investigation, 2011 dan Yahaya, 2010).

5. Keterampilan Komunikasi

Keterampilan komunikasi adalah kemampuan menghadapi proses interaksi manusia melalui penerimaan dan pemberian pesan yang terdiri dari pemberi pesan dan penerima pesan dengan tujuan untuk mempengaruhi cara berpikir dan pola perilaku sehingga terjadinya perubahan pada individu maupun lingkungan dalam bentuk verbal dan nonverbal (Wiryanto, 2004).

6. Keterampilan Mengelola Teknologi dan Informasi

Keterampilan mengelola teknologi dan informasi merupakan kemampuan individu dalam memahami, mengoperasikan, dan mengakses teknologi dan informasi yang hendak 
dikelola, serta menganalisa dan menerapkan pengetahuan dan keterampilan dari berbagai disiplin ilmu (misalnya seni, bahasa, sains, teknologi, matematika, ilmu sosial, dan humaniora) (Trought, 2012).

7. Keterampilan Matematik

Keterampilan matematik merupakan kemampuan individu dalam mengklasifikasi data, menentukan hal-hal yang dapat diukur dan dihitung dari proyek atau tugas yang dikerjakan, lalu menganalisa, menafsirkannya dan mempresentasikan data tersebut dalam format visual (Trought, 2012).

8. Keterampilan Kepemimpinan

Keterampilan kepemimpinan merupakan kemampuan individu dalam proses mempengaruhi kegiatan individu atau kelompok untuk mencapai tujuan bersama. Keterampilan dalam memimpin orang lain saling menyesuaikan antara kepribadian pemimpin dan yang dipimpin (Soekarso \& Putong, 2015).

9. Keberanian Berusaha

Keberanian berusaha merupakan kemampuan individu mendorong afeksi untuk mengambil resiko dan siap dalam menghadapi tantangan (Trought, 2012).

10. Kecerdasan Emosional

Kecerdasan emosional merupakan kemampuan individu memanajemen diri, memanajemen hubungan, dan memanajemen lingkungan dari sisi emosional secara efektif. Kemampuan mengelola kecerdasan emosional menuntut individu agar mandiri, realitis, dan fleksibel (Trought, 2012).

Keterampilan kerja merupakan kumpulan keterampilan yang mendorong individu atau kelompok mampu masuk, berkembang, dan mencapai tujuan dalam dunia karier. Individu maupun kelompok perlu merancang strategi agar memiliki kemampuan-kemampuan penunjang karier. Keterampilan kerja yang dimiliki oleh individu maupun kelompok bukan hanya memberikan dampak positif kepada bidang karir yang digeluti, tapi juga memberikan dampak positif kepada diri sendiri.
B. Tugas Staf Bidang Layanan Rehabilitas Sosial, Pemulangan, dan Reintegrasi Sosial P2TP2A

1. Melakukan pendampingan selama proses penanganan kasus.

2. Melakukan konseling.

3. Melakukan koordinasi dengan instansi terkait untuk pemulangan korban.

4. Membuat laporan perkembangan proses pendampingan pemulangan dan rehabilitasi sosial.

5. Melakukan pemantauan sekurangkurangnya tiga bulan setelah korban dipulangkan kekeluarganya.

C. Pelatihan

Pelatihan (training) didefinisikan sebagai kegiatan yang dilakukan untuk memperoleh pengetahuan atau pengembangan keterampilan yang dirancang untuk membantu staf meningkatkan kinerja di pekerjaan. Pengembangan didefinisikan sebagai pengalaman belajar yang dirancang untuk meningkatkan pertumbuhan pribadi dan profesional, tetapi tidak harus terkait langsung dengan pekerjaan (Kettner, 2002). Pelatihan dan pengembangan mengacu pada memperoleh atau mentransfer pengetahuan, keterampilan, dan kemampuan yang dibutuhkan dalam proses melakukan aktivitas atau fungsi tertentu (Niazi, 2011). Kegiatan pelatihan memberikan dampak bagi organisasi dan pekerja secara bersamaan (Abushamsieh, 2014).

D. Keterampilan Kerja Staf Bidang Layanan Rehabilitasi Sosial, Pemulangan, dan Reinegrasi Sosial P2TP2A

Staf bidang Layanan Rehabilitasi Sosial, Pemulangan, dan Reintegrasi Sosial P2TP2A diamanatkan menjalankan tugas dalam rangka memberikan perlindungan, penanganan dan pemenuhan hak korban, perempuan maupun anak. Salah satu upaya yang dapat dilakukan untuk memenuhi kompetensi staf dalam menjalankan tugas adalah melalui pelatihan keterampilan kerja. Berikut ini adalah ciri-ciri keterampilan kerja yang perlu dimiliki oleh staf sebagai bagian 
dari rencana pelatihan:

1. Keterampilan Manajemen Diri

Pada keterampilan kerjasama, staf diharapkan memiliki kemampuan untuk menghormati orang lain, bekerja dengan orang lain, bernegosiasi atau meyakinkan, berkontribusi dalam diskusi, proyek, atau tugas, dan memiliki kesadaran akan saling ketergantungan dengan orang lain (Central Bureau of Investigation, 2011).

Berikut ini adalah ciri-ciri staf yang memiliki keterampilan manajemen diri (Trought, 2012):

a. Memiliki inisiatif dan kemandirian untuk memanajemen diri.

b. Mampu mengatur waktu pendampingan selama proses penanganan kasus secara efektif.

c. Mampu mengatur waktu konseling secara efektif.

d. Memiliki inisiatif untuk memberikan pelayanan.

e. Mampu membuat perencanaan dan mengorganisir kegiatan yang akan dilakukan.

f. Mampu belajar, melakukan refleksi, dan evaluasi dari pengalaman diri sendiri dan orang lain sebagai upaya memaksimalkan pelaksanaan tugas.

g. Mampu melihat diri punya kesempatan untuk perbaikan.

h. Mampu menjaga kesehatan.

i. Mampu mengetahui dan memahami perasaan dan pikiran diri sendiri.

j. Mampu mengelola perasaan dan pikiran diri sendiri.

k. Mampu memanfaatkan potensi diri untuk memberikan pelayanan.

2. Keterampilan Kerjasama

Pada keterampilan kerjasama staf diharapkan memiliki kemampuan untuk menghormati orang lain, bekerja dengan orang lain, bernegosiasi atau meyakinkan, berkontribusi dalam diskusi, proyek, atau tugas, dan memiliki kesadaran akan saling ketergantungan dengan orang lain (Central Bureau of Investigation, 2011).

Berikut ini adalah ciri-ciri staf yang memiliki keterampilan kerjasama (Trought, 2012 dan Sari, 2014):

a. Menerapkan asas kemitraan dalam menjalankan tugas.

b. Mampu menghormati stakeholder yang terlibat di dalam layanan.

c. Mampu bekerja dengan stakeholder yang terlibat di dalam layanan.

d. Mampu menentukan pihak yang perlu dilibatkan dalam proses pemberian layanan.

e. Mampu melakukan koordinasi dengan instansi terkait untuk pemulangan korban.

f. Mampu melakukan negosiasi dengan pihak yang perlu dilibatkan dalam proses pemberian layanan.

g. Mampu berkontribusi dalam pencapaian tujuan kerja.

h. Memiliki kesadaran akan saling ketergantungan dengan orang lain.

i. Berorientasi pada tercapainya tujuan yang baik.

j. Memperhatikan kepentingan bersama.

k. Memiliki prinsip untuk saling menguntungkan.

3. Kesadaran pada Karir

Dalam meningkatkan kesadaran pada karir, staf diharapkan memiliki kemampuan untuk mengenali karir sehingga mampu memahami target, tujuan, dan tantangan dalam karir (Syafitri \& Heriyanto, 2013).

Berikut ini adalah ciri-ciri staf yang memiliki kesadaran pada karir (Trought, 2012):

a. Mampu mengerti dan memahami diri sendiri.

b. Mampu menjadi diri sendiri.

c. Mengetahui dan memahami potensi yang dimiliki.

d. Mengetahui dan memahami keputusan yang diambil.

e. Mengetahui dan memahami perasaan yang dirasakan (afeksi).

f. Mengetahui dan memahami nilai-nilai yang dimiliki.

g. Mengetahui dan memahami visi, misi, dan tujuan P2TP2A.

h. Mampu menerapkan prinsip dan asas yang relevan dalam pelaksanaan layanan.

i. Mampu memahami target, tujuan, 
dan tantangan yang harus dihadapi dalam bekerja.

j. Memiliki pemahaman dasar tentang pendorong kesuksesan utama pekerjaan.

k. Memiliki inovasi, tanggung jawab, dan mampu mengambil risiko yang dapat diperhitungkan.

I. Memiliki kesadaran pada prosedur kesehatan dan keselamatan pribadi dan kelompok.

m. Mampu bertindak sesuai dengan kesepakatan tim.

4. Keterampilan Menyelesaian Masalah

Pada keterampilan menyelesaikan masalah staf diharapkan memiliki kemampuan dalam mengenali, mengidentifikasi, mendefinisikan, menganalisa fakta dan situasi dari masalah yang dihadapi, serta menerapkan pemikiran kreatif untuk mengembangkan solusi yang tepat melalui penafsiran strategi yang memungkinkan (Central Bureau of Investigation, 2011 dan Yahaya, 2010).

Berikut ini adalah ciri-ciri staf yang memiliki keterampilan menyelesaikan masalah (Trought, 2012):

a. Mampu menganalisa fakta dan situasi stakeholder yang terlibat di dalam layanan.

b. Memiliki pemikiran kreatif dalam penafsiran strategi.

c. Mampu mengidentifikasi dan mengenal masalah yang ada selama proses layanan.

d. Mampu mendefinisikan dan menggambarkan masalah.

e. Mampu menafsirkan strategi yang memungkinkan.

f. Mampu bertindak sesuai dengan strategi.

g. Mampu melakukan evaluasi dan perencanaan tindak lanjut.

h. Memiliki inisiatif dalam menghadapi masalah.

5. Keterampilan Komunikasi

Pada keterampilan komunikasi staf diharapkan memiliki kemampuan berinteraksi melalui penerimaan dan pemberian pesan yang terdiri dari pemberi pesan dan penerima pesan dengan tujuan untuk mempengaruhi cara berpikir dan pola perilaku sehingga terjadinya perubahan pada individu maupun lingkungan dalam bentuk verbal dan nonverbal (Wiryanto, 2004).

Berikut ini adalah ciri-ciri staf yang memiliki keterampilan komunikasi (Trought, 2012):

a. Memahami konteks pesan yang disampaikan.

b. Mampu mengenali lawan bicara.

c. Mampu memilih media yang tepat untuk berkomunikasi.

d. Mampu memilih kata-kata dalam komunikasi dengan seksama.

e. Mampu mengantisipasi situasi yang memungkinkan penerima pesan salah tafsir terhadap pesan yang diterima.

f. Memahami penggunaan bahasa internet.

g. Mampu berkomunikasi dengan intonasi, artikulasi, dan ekspresi visual yang tepat.

h. Mampu berkomunikasi secara efektif.

6. Keterampilan Mengelola Teknologi dan Informasi

Pada keterampilan mengelola teknologi dan informasi staf diharapkan memiliki kemampuan dalam memahami, mengoperasikan, dan mengakses teknologi dan informasi yang hendak dikelola, serta menganalisa dan menerapkan pengetahuan dan keterampilan dari berbagai disiplin ilmu (misalnya seni, bahasa, sains, teknologi, matematika, ilmu sosial, dan humaniora) (Trought, 2012).

Berikut ini adalah ciri-ciri staf yang memiliki keterampilan mengelola teknologi dan informasi (Trought, 2012):

a. Bersedia untuk belajar keterampilan mengelola teknologi dan informasi baru.

b. Memiliki pemahaman dasar mengenai teknologi dan informasi.

c. Memiliki berbagai keterampilan dasar teknologi dan informasi.

d. Menerapkan teknologi dan informasi sebagai alat manajemen.

e. Mampu memanfaatkan teknologi dan 
informasi untuk melakukan pendampingan selama proses penanganan kasus.

f. Mampu memanfaatkan teknologi untuk komunikasi dengan stakeholder yang terlibat di dalam layanan.

g. Mampu memanfaatkan teknologi untuk membuat laporan perkembangan proses pendampingan, pemulangan, dan rehabilitasi sosial.

h. Mampu memanfaatkan teknologi untuk melakukan pemantauan korban yang dipulangkan minimal tiga bulan setelah.

i. Menggunakan teknologi dan informasi untuk mengatur data.

j. Memiliki pengetahuan tentang kesehatan dan keselamatan kerja dalam menggunakan teknologi dengan cara yang aman dan sehat.

k. Mampu mencari, mengumpulkan, dan mengatur informasi menggunakan teknologi dan sistem informasi yang sesuai.

7. Keterampilan Matematik

Pada keterampilan matematik staf diharapkan memiliki kemampuan dalam mengklasifikasi data, menentukan hal-hal yang dapat diukur dan dihitung dari proyek atau tugas yang dikerjakan, lalu menganalisa, menafsirkannya dan mempresentasikan data tersebut dalam format visual (Trought, 2012).

Berikut ini adalah ciri-ciri staf yang memiliki keterampilan matematik (Trought, 2012):

a. Mampu memahami arti berhitung sesuai dengan peran sebagai staf bidang layanan rehabilitasi sosial, pemulangan, dan reintegrasi sosial.

b. Memiliki pemahaman tentang tugas aritmatika seperti penambahan, pengurangan, perkalian dan pembagian.

c. Mampu menganalisa data kuantitatif dan kualitatif.

d. Mampu menganalisa data hasil konseling.

e. Mampu menafsirkan dan mempresentasikan data dalam format visual.

f. Mampu memutuskan apa yang perlu diukur atau dihitung.

g. Mampu mengamati dan mencatat data hasil konseling dengan menggunakan metode, alat, dan teknologi yang tepat.

h. Mampu mengamati dan mencatat data hasil koordinasi dengan instansi terkait untuk pemulangan korban dengan menggunakan metode, alat, dan teknologi yang tepat.

i. Mampu membuat perkiraan dan verifikasi perhitungan.

j. Mampu membuat laporan perkembangan proses pendampingan pemulangan dan rehabilitasi sosial yang valid dan kredibel.

8. Keterampilan Kepemimpinan

Pada keterampilan kepemimpinan staf diharapkan memiliki kemampuan dalam proses mempengaruhi kegiatan individu atau kelompok untuk mencapai tujuan bersama. Keterampilan dalam memimpin orang lain saling menyesuaikan antara kepribadian pemimpin dan yang dipimpin (Soekarso \& Putong, 2015).

Berikut ini adalah ciri-ciri staf yang memiliki keterampilan kepemimpinan (Trought, 2012):

a. Mampu memahami kepribadian diri sendiri.

b. Mampu memahami kepribadian rekan kerja.

c. Mampu memahami dan menghadapi tantangan yang ada dalam bidang layanan rehabilitasi sosial, pemulangan, dan reintegrasi sosial.

d. Memahami dan menyadari tujuan bersama yang perlu dicapai dengan rekan kerja.

e. Mampu mempengaruhi kegiatan individu atau kelompok untuk mencapai tujuan bersama.

f. Inovatif dan kreatif untuk menghadapi tantangan dalam memimpin.

9. Keberanian Berusaha

Dalam meningkatkan keberanian berusaha, staf diharapkan memiliki kemampuan mendorong afeksi untuk 
mengambil resiko dan siap dalam menghadapi tantangan (Trought, 2012).

Berikut ini adalah ciri-ciri staf yang memiliki keberanian berusaha (Trought, 2012)
a. Kreatif dan inovatif.
b. Mampu keterampilan inisiatif.
mengembangkan
c. Mampu mengidentifikasi memanfaatkan peluang.
d. Mampu mengembangkan produk dan proses baru dari dalam bidang layanan dan institusi.
e. Memiliki ketahanmalangan yang cukup tinggi.

10. Kecerdasan Emosional

Dalam meningkatkan kecerdasan emosional, staf diharapkan memiliki kemampuan memanajemen diri, memanajemen hubungan, dan memanajemen lingkungan dari sisi emosional secara efektif. Kemampuan mengelola kecerdasan emosional menuntut individu agar mandiri, realitis, dan fleksibel (Trought, 2012).

Berikut ini adalah ciri-ciri staf yang memiliki kecerdasan emosional (Trought, 2012)
a. Mampu merasakan emosi (afeksi).
b. Mampu bersikap simpati dan empati terhadap penerima layanan.
c. Mampu mengendalikan diri.
d. Mampu menginspirasi, mempengaruhi, mengembangkan orang lain, menantang status quo, dan mengelola konflik.
e. Mampu mengenali bagaimana perasaan akan mempengaruhi kinerja pekerjaan.

f. Mampu mengelola dan merespon tantangan dengan tepat.
g. Mampu membuat keputusan berdasarkan fakta dan data yang berkaitan.

h. Mampu mengakses dan membangkitkan emosi.

i. Memiliki pengetahuan dan memahami emosional.

Keterampilan kerja merupakan kumpulan keterampilan yang dapat mendorong staf bidang Layanan Rehabilitasi Sosial,
Pemulangan, dan Reintegrasi Sosialuntuk mampu masuk, berkembang, dan mencapai visi, misi, dan tujuan P2TP2A. Lembaga perlu merancang rencana pelatihan keterampilan kerja yang efektif dengan memiliki pengetahuan mengenai ciri-ciri keterampilan kerja yang perlu dimiliki oleh staf terkait. Keterampilan kerja yang dimiliki oleh staf bukan hanya akan memberikan dampak positif kepada lembaga, tapi juga memberikan dampak positif kepada diri sendiri.

\section{Simpulan dan Saran}

P2TP2A sebagai lembaga yang memiliki amanat untuk memberikan penanganan kepada korban kekerasan secara komprehensif menjadikan lembaga tersebut memiliki peran yang krusial dalam peningkatan kesejahteraan sosial di Indonesia. Staf bidang Layanan Rehabilitasi Sosial, Pemulangan, dan Reintegrasi Sosial P2TP2A memiliki tugas yang berkenan langsung dengan korban sebagai penerima layanan maupun dengan mitra terkait. Hal tersebut membuat staf diharapkan mampu memiliki keterampilan kerja. Rumusan ciri-ciri keterampilan kerja yang perlu dimiliki staf bidang Layanan Rehabilitasi Sosial, Pemulangan, dan Reintegrasi Sosial dalam rencana pelatihan diharapkan mampu memberikan gambaran pencapaian sebagai upaya peningkatan profesionalitas kerja.

Penelitian ini terbatas pada hanya rumusan ciriciri keterampilan kerja P2TP2A yang perlu dimiliki staf bidang Layanan Rehabilitasi Sosial, Pemulangan, dan Reintegrasi Sosial. Penelitian ini dapat dikembangan lebih lanjut oleh peneliti selanjutnya yang berminat. Pengembangan penelitian ini dapat diarahkan kepada pendekatan yang lebih baik dan lebih profesional dengan menyiapkan rencana pelatihan keterampilan kerja yang lengkap. Rencana pelatihan tersebut dapat membantu memastikan bahwa staf berprestasi di tingkat tertinggi.

\section{DAFTAR PUSTAKA}

Abushamsieh, Khalil, dkk. (2014). Training Strategies, Theories and Types. Journal of Accounting: Business \& Management, 21(1), 12-26. 


\begin{tabular}{|c|c|c|c|c|}
\hline Share: Social Work Jurnal & VOLUME: 10 & NOMOR: 1 & HALAMAN: $96-103$ & $\begin{array}{c}\text { ISSN: 2339-0042 (p) } \\
\text { ISSN: 2528-1577 (e) } \\
\text { DOI: 10.24198/share.v10i1.26896 }\end{array}$ \\
\hline
\end{tabular}

Central Bureau of Investigation . (2011). Working Towards Your Future: Making the Most of Your Time in Higher Education. London: National Union of Students.

Creswell, John W. (2014). Research Design: Qualitative, Quantitative, and Mixed Methods Approaches (4th ed.). Thousand Oaks, California: SAGE Publications.

Employability Skills. (2017, September 12). Retrieved from The University of Sydney: https://sydney.edu.au/careers/students/c areer-adviceanddevelopment/employability-skills.html

Gazier, B. (2001). The Complexity of Policy Notion. In P. Weinert, P. Weinert, M. Baukens, P. Bollerot, M. Pineschi, \& U. Walwei (Eds.), Employability: From Theory to Practice (p. 5). London: Transaction Publisher.

Kettner, Peter M. (2002). Achieving Excellence in The Management of Human Service Organizations. Boston: Pearson Education Company.

Niazi, A. (2011). Training and development strategy and it's role in organizational performance. MS Scholar, Iqra University Islamabad Campus, Pakistan, Journal of Public Administration and Governance. ISSN 2161-7104.

Peraturan Menteri Pemberdayaan Perempuan dan Perlindungan Anak Republik Indonesia
Nomor 5 Tahun 2010 Tentang Panduan Pembentukan dan Pengembangan Pusat Pelayanan Terpadu.

Soekarso, \& Putong, I. (2015). Kepemimpinan: Kajian Teoritis dan Praktis. Jakarta: Buku\&Artikel Karya Iskandar Putong.

Suhartini, Y. (2015). Pengaruh Pengetahuan, Keterampilan dan Kemampuan Karyawan Terhadap Kinerja Karyawan. AKMENIKA, 12 (2), 660-673.

Syafitri, M., \& Heriyanto, M. (2013). Kesadaran, Lingkungan, dan Budaya Kerja. Jurnal Administrasi Pembangunan, 1 (2), 101218.

The Conference Board of Canada. (2000). Employability Skills. Retrieved October 30, 2017, from The Conference Board of Canada:

https://www.conferenceboard.ca/docs/de faultsource/educpublic/esp2000.pdf?sfvrsn $=0$

Trought, F. (2012). Brilliant Employability Skills (2nd ed.). United Kingdom: Pearson Education Limited.

Wiryanto. (2004). Pengantar IImu Komunikasi. Jakarta: Grasindo.

Yahaya, A. (2010). Bab 8 : Penyelesaian Masalah. In T. P. Malaysia, Psikologi Pendidikan (pp. 1-9). Johor: Universiti Teknologi Malaysia. 